\title{
Regional Integration in Asia and Its Effects on the EU and North America
}

December 26, 2008

\author{
Hiro Lee
}

Professor, Osaka School of International Public Policy, Osaka University

Robert F. Owen

Professor, Institute of Economics and Management of Nantes, University of Nantes

Dominique van der Mensbrugghe

Senior Economist, The World Bank

[Keywords] Regional integration, FTA, East Asia, welfare effects, CGE model [JEL codes] C68, F15, F17

[Abstract] Consequences of free trade agreements (FTAs) among the ASEAN+3 countries and ASEAN+6 countries are explored using a dynamic computable general equilibrium (CGE) model. Quantitative assessments of intra and extra-regional effects on welfare, trade and output are offered. When both trade facilitation and endogenously determined productivity are included in the FTA scenarios, Singapore, other ASEAN countries and China would be able to realize relatively large welfare gains, while the welfare effects on the EU and North America are negligible. The trade and output effects on the latter two regions are also relatively small, with the notable exception of crops, other than rice, in North America.

Correspondence to: Hiro Lee, OSIPP, Osaka University, 1-31 Machikaneyama-cho, Toyonaka, Osaka 560-0043, Japan. Email: hlee@osipp.osaka-u.ac.jp 


\title{
Regional Integration in Asia and Its Effects on the EU and North America*
}

\author{
Hiro Lee \\ Osaka School of International Public Policy \\ Osaka University, Osaka 560-0043, Japan \\ E-mail: hlee@osipp.osaka-u.ac.jp \\ Robert F. Owen \\ Institute of Economics and Management of Nantes \\ University of Nantes, 44322 Nantes Cedex 03, France \\ E-mail:RobertOwen@compuserve.com \\ Dominique van der Mensbrugghe \\ The World Bank, Washington, DC 20433, USA \\ E-mail: dvandermensbrugg@worldbank.org
}

December 2008

\begin{abstract}
Consequences of free trade agreements (FTAs) among the ASEAN+3 countries and ASEAN+6 countries are explored using a dynamic computable general equilibrium (CGE) model. Quantitative assessments of intra and extra-regional effects on welfare, trade and output are offered. When both trade facilitation and endogenously determined productivity are included in the FTA scenarios, Singapore, other ASEAN countries and China would be able to realize relatively large welfare gains, while the welfare effects on the EU and North America are negligible. The trade and output effects on the latter two regions are also relatively small, with the notable exception of crops, other than rice, in North America.
\end{abstract}

JEL classification codes: C68, F15, F17

Keywords: regional integration, FTA, East Asia, welfare effects, CGE model

\footnotetext{
* We have benefitted from the helpful comments of Michael G. Plummer, David J. Green, Richard Pomfret, and other participants at the Conference on "Asian Economic Integration in a Global Context,” Rimini, Italy, August 29-31, 2008. Lee gratefully acknowledges financial support from the Japan Society for the Promotion of Science program, grants-in-aid for basic research (B-19330050).
} 


\section{Introduction}

In the past decade a growing number of bilateral and plurilateral free trade agreements (FTAs) involving Asian countries have been signed or ratified, while a large number of FTAs are currently being negotiated (e.g. Australia-China, Australia-Japan and Japan-Korea). The ASEAN countries now have FTAs with the three major trading partners in the region (i.e., China, Japan and Korea). In addition, alternative free trade proposals encompassing ASEAN with either China, Japan and Korea (ASEAN+3 FTA) or China, Japan, Korea, India, Australia and New Zealand (ASEAN+6 FTA) are actively being considered. Furthermore, these envisaged FTAs entail a more ambitious policy agenda, since they are of a more comprehensive scope and coverage than traditional FTAs. Specifically, these international policy initiatives conceivably aim to cover trade facilitation (including customs procedures and harmonization of standards), investment liberalization, intellectual property protection, technical assistance and development cooperation. ${ }^{1}$ Yet, certain key sensitive commodities, such as rice and several other agricultural products, remain excluded from these integration processes. ${ }^{2}$

A regional integration arrangement among either the ASEAN+3 countries or the ASEAN+6 countries is expected to have non-negligible effects on countries outside of the preferential trade zone, as the reduction in barriers across partners leads to a re-orientation of trade and investment, including not just trade and FDI creation, but also potential diversion effects. This paper uses a dynamic computable general equilibrium (CGE) model to evaluate the extent of trade adjustments, as well as other economic effects, that the enlargement and redefinition of a free-trade agreement to encompassing either ASEAN+3 or ASEAN+6 could have on the European Union (EU) and North America. The model allows both for trade facilitation (e.g., streamlining customs procedures) and endogenously determined productivity, where the latter is assumed to be positively correlated with economic openness. Indeed, in this regard it has often been argued that one

\footnotetext{
${ }^{1}$ Owen (2001) has argued that there is a critical shortfall between the extent of economic integration in Southeast Asia and, in this regard, the accomplishments of the European Union since the mid-1980s. A number of the lessons from the EU experience are suggested to be of general applicability for understanding the political economy of the integration process elsewhere.

2 Plummer (2007) suggests that exclusions of individual products should be minimized on efficiency grounds. He examines the extent to which eleven of the existing FTAs in Asia conform to best practices of regionalism, including comprehensive product coverage, low and symmetric rules of origin, intellectual property protection and investment-related provisions.
} 
of the primary benefits of greater outward orientation is the internalization of factors, practices and processes that embody and propagate productivity growth. Notably, there is substantial evidence, for example in the case of the EU, that such productivity growth can be generated by increased international competition following domestic market liberalization.

The quantitative effects of various FTA proposals for East Asia have been assessed on the basis of different CGE models. ${ }^{3}$ In general, these studies find that: (1) real income increases for most of the FTA members, while declining for at least some non-members; (2) the aggregate gain for FTA members is larger when the overall size of the integrating region is larger; (3) if FTAs are confined to tariff liberalization for only merchandize trade, welfare gains are limited; (4) when FTAs also include both trade liberalization in services and trade facilitation, the gain to each member increases, while the aggregate loss experienced by non-members decreases; (5) the overall impact of FTAs becomes even greater when the model incorporates increasing returns to scale and imperfect competition in at least some sectors; and, finally, (6) more beneficial effects are suggested for model simulations of FTAs, which also incorporate investment and growth effects. Furthermore, Kawai and Wignaraja (2007) assert that consolidation of multiple and overlapping FTAs into a single Asian FTA would help alleviate the negative effects of different rules of origin associated with individual FTAs. In addition, their analysis suggests that it would be desirable for Asia to strengthen economic ties, ultimately in the form of extended FTAs, with not only North America and eventually other Pacific Rim countries, as under APEC, but also with the European Union. ${ }^{4}$

The organization of the remainder of the paper is as follows. The next section provides an overview of the basic CGE modeling framework, while a description of the baseline and policy scenarios is then offered in section 3. In section 4 the computational results are assessed and associated policy implications are deduced. The final section summarizes the principal conclusions from this research, while identifying conceivable extensions, along with certain limitations of the analysis. In an appendix a sensitivity

\footnotetext{
3 See, for example, Dee (2007), Kawai and Wignaraja (2007), Lee and van der Mensbrugghe (2008), Park (2006), Scollay and Gilbert (2001), Urata and Kiyota (2005), and Zhai (2006).

${ }^{4}$ Studies by the Asian Development Bank (2008a,b), as well as certain other recent research, arrive at similar policy assessments.
} 
analysis of the robustness of the welfare effects is scrutinized by altering the values of certain key model parameters.

\section{Overview of the CGE Modeling Framework}

The numerical simulations undertaken for this paper are derived from the World Bank’s LinKAGE model, described in detail by van der Mensbrugghe (2005). This model has been extensively used for the comparative analysis of alternative trade integration scenarios, including most recently an assessment of various Doha Round proposals by Anderson et al. (2006), as well as the evaluation of the costs and benefits of different regional trade agreements presented by the World Bank (2005). In a number of respects the structure of the LINKAGE model is similar to two other widely used and cited global trade models, specifically, the Purdue-based GTAP, as elaborated in Hertel (1997) and MIRAGE, sponsored by CEPII in Paris and discussed by Bchir et al. (2002). ${ }^{5}$ The core of all three frameworks is a comparative static CGE model, although all three incorporate specific variations. For example, LINKAGE and MIRAGE are typically used for undertaking a recursive dynamic analysis, where specific assumptions regarding population and labor growth, capital accumulation and productivity are invoked in order to develop a baseline scenario from which different policy shocks are then examined. ${ }^{6}$

The LINKAGE model entails a standard CGE paradigm, built around the circular flow of the economy, where on the supply side, goods and services are produced by combining intermediate inputs and factors (e.g., labor, capital and land). A nested constant elasticity of substitution (CES) structure captures the substitution and complementarity effects across intermediate goods and factors, where in most sectors, the degree of substitution between capital and labor constitutes the core relation, while intermediate goods are taken to be a fixed proportion of output. ${ }^{7}$ A second node of the circular flow,

\footnotetext{
${ }^{5}$ van der Mensbrugghe (2006) offers a discussion of representative numerical results based on the LINKAGE model, along with a summary comparison to those using GTAP.

6 Although a dynamic version of GTAP has been developed by Ianchovichina and McDougall (2000), a majority of GTAP applications involve a static version of that model.

7 One strength of the LINKAGE model is a rather detailed formulation for agricultural production, in which land use plays a key role, as, for example, in the choice between intensive versus extensive crop production, or range-fed, as compared to other smaller livestock undertakings. The energy sector also constitutes a separate activity, which is assumed to be a near-complement to capital in the short run, but a substitute for capital in the long run.
} 
relating to economic agents' supply of the needed factors of production and their factor earnings, is specified in the LINKAGE framework by a single representative household that receives all factor income. Finally, a third node, characterizing agents' demand for final goods and services, uses the extended linear expenditure system (ELES), as set forth by Lluch (1973), whereby purchases of goods and services are simultaneously determined with savings. As in the conventional CGE model, such as those developed by Dervis et al. (1982) and Löfgren et al. (2002), constant returns to scale and perfect competition are assumed in the goods and services market, and product and factor prices are determined by equilibrium in their respective markets.

An open-economy CGE model entails a somewhat more complicated structure, since domestic production needs to be allocated between domestic and multiple foreign markets, while, analogously, domestic demand can be met by goods produced either domestically or from abroad. In this regard, the standard LINKAGE model assumes that domestic output is supplied homogeneously from all markets, with the law of one price holding, so that producers can switch their sales across market destinations costlessly. ${ }^{8}$ On the demand side, products are differentiated for both producers and final consumers on the basis of their origin, in keeping with the so-called Armington assumption. ${ }^{9}$ More specifically, the LINKAGE framework relies on a nested CES structure, where at the top nested level, each agent chooses to allocate aggregate demand between locally produced goods and an aggregate import bundle, while minimizing the overall cost of the aggregate demand bundle. At the second level, aggregate import demand is allocated across different trading partners, again using a CES specification, wherein the aggregate costs of imports are minimized. This open-economy formulation generates a much broader set of market equilibria, whereby the supply and demand for each traded good is required to be equal. Hence, if the closed economy model had $n$ equilibria for $n$ goods, the global model has $r \mathrm{x}$ $n$ equilibria for non-traded goods and $r \times r \times n$ equilibria for traded goods, where $r$ is the number of modeled countries/regions.

\footnotetext{
${ }^{8}$ The model also allows for a finite constant elasticity of transformation (CET) function, which applies across market destinations, and uses a two-level nested CET specification. At the top nested level, production is allocated between the domestic market and aggregate exports, so as to maximize revenue. At the second level, a CET function is used to allocate aggregate exports across foreign markets, while maximizing total export revenue.
}

${ }^{9}$ See Armington (1969). 
The model distinguishes between four interrelated price categories for traded goods, which entail four separate instruments. The initial price producers receive for their exported goods is designated as $P E$, while the FOB price, denoted as WPE, reflects domestic export taxes or subsidies. The CIF price, WPM, includes the trade and transport margin, represented by the ad valorem wedge $\zeta$, as well as frictional trade costs, corresponding to an iceberg parameter $\lambda .{ }^{10}$. Thus, the relationship between the FOB and CIF prices is given by

$$
W P M_{r, r^{\prime}, i}=\left(1+\zeta_{r, r^{\prime}, i}\right) W P E_{r, r^{\prime}, i} / \lambda_{r, r^{\prime}, i}
$$

for the different $r$ and $r^{\prime}$ combinations of exporting and importing regions/countries and $i$ commodities. Finally, the domestic price of imports, $P M$, equals the CIF price, WPM, plus tariffs and/or the tariff-equivalent effects of a range of possible commercial policies. In the subsequent analysis, an increase in $\lambda_{r, r^{\prime}, i}$ corresponds to a reduction in trade-related risks, lower administrative barriers to trade (e.g., customs procedures), and/or a fall in technical barriers (e.g., mutual recognition of product standards). In sum, trade facilitating policy initiatives imply an increase in the value of $\lambda_{r, r^{\prime}, i}$.

Foreign capital flows, including notably foreign direct investment (FDI), are taken to be exogenous in the current research. Nonetheless, it is fully recognized that it would be worthwhile to expand this feature of the analysis to allow for endogenous determination of FDI in light not only of the process of regional integration in Asia per se, but also associated policy initiatives aimed at promoting a more favorable investment environment with reduced restrictions facing multinational enterprises (MNEs). In Asia, where many countries are characterized by relatively high growth rates and/or low efficiency wages, trade and FDI are closely interlinked. In this regard, there is also an essential distinction between the determinants and impact of market seeking, as compared with cost efficiency, oriented FDI. Indeed, a number of countries in Asia have experienced extensive outsourcing and delocalization by MNEs, not only from the EU, Japan, the United States and other industrialized countries, but also involving intra-regional Asian flows from other source countries. There is typically a significant degree of specificity in these flows,

\footnotetext{
10 Such an iceberg specification for transportation costs, was formulated by Samuelson (1952), based on a concept developed earlier by von Thünen.
} 
depending on sectors, as well as host and home countries. Allowing for such capital flows, stimulated by heightened rates of return arising from expanded market access, could significantly raise the gains from regional trade reform. ${ }^{11}$ In a preliminary investigation on the impact of further trade and investment liberalization for APEC, Lee and van der Mensbrugghe (2005) find that considering the effects of dismantling obstacles to FDI, in addition to those of trade liberalization, would significantly boost the welfare gains for most APEC economies.

Final demand in the model is split into three categories, involving a representative household, the public sector and the investment account. Public expenditure is specified as fixed as a share of GDP and investment is determined by the total savings of the economy, thereby leading to a different pattern of demand expenditures relative to that of households. There are three closure rules relating to final goods expenditures in each country. First, the government deficit is assumed fixed, while a lump sum tax borne by the representative household is endogenously determined, so as to meet the public deficit target. Thus, trade reform can generate an increase in the direct taxation of consumers, as a result of reduced tariff revenues. Second, investment equals the sum of private, public and foreign savings. Thirdly, the level of foreign saving is fixed; i.e., the current account balance is taken as exogenously given. The latter implies that an ex ante change in import demand generates an offsetting adjustment in the real exchange rate.

The model was calibrated to a 2001 base year using version 6 of the GTAP database. ${ }^{12}$ Although the LinKAGE model can be analyzed for 87 countries/regions and 57 sectors, this more detailed database has been aggregated in the current analysis, and relates to 12 countries/regions and 22 sectors as shown in Table 1. More specifically, the country/region breakdown includes six individual Asian economies, an aggregation of the ASEAN economies other than Singapore, as well as regional country groupings for Australia/New Zealand, North America, the EU-15, new EU member states and the rest of the world. The values of key parameters, such as demand, supply and substitution elasticities, are based upon the previous empirical estimates. The model calibration

\footnotetext{
11 Following the Single European Act and the 1992 Program, there was a remarkable upsurge with the European Community in both intra-regional FDI flows and those from outside the EC. More recently, and while of a more unidirectional nature, the expansion to the EU from 15 to 27 countries has generated substantial investment by MNEs in Eastern Europe, often aimed at reducing wage costs.
}

12 A detailed description of version 6 of the GTAP database is offered by Dimaranan (2006). 
primarily consists of calculating share and shift parameters to fit the model specifications to the observed data, so as to be able to reproduce a solution for the base year. ${ }^{13}$

\section{The Baseline and Policy Scenarios}

\subsection{The Baseline Scenario}

In order to evaluate the effects of regional integration in Asia, the baseline scenario is first established, showing the path of each of the 12 economies/regions in the absence of region-wide FTAs in Asia over the period 2001-2015. Population and labor force growth are assumed exogenous, in line with assumptions made by the UN, such that the growth of the labor force growth equals the growth of the working age population (ages 15-64). Real GDP growth rates are also exogenous in the baseline in order to be consistent with the actual growth rates for 2001-2007 and the World Bank's growth forecast for 2008-2015. The basic capital accumulation function equates the current capital stock to the depreciated stock inherited from the previous period plus gross investment. For the trade liberalization policy scenarios under consideration, capital accumulation can be an important transmission of growth, since reduced taxes on imports of capital goods can generate an investment boost. In the baseline the trade and transport margin is assumed to decline by 1 percent per annum in every country/region, which is consistent with the recent trends.

Several assumptions are critical for the calibration of productivity levels. Notably, whereas agricultural productivity is fixed in the baseline using results from empirical studies, including those proposed by Martin and Mitra (2001), sectoral productivity in non-agricultural sectors is determined by three components. These include a uniform economy-wide factor that is calibrated to achieve the given GDP target, a sector-specific factor related to the degree of openness, and a shift term that permits constant deviations across sectors beyond the differences in openness. More specifically, the sector-specific factor intended to capture the sensitivity of changes in productivity to an economy's openness, $\chi_{i, t}$, is given by the formula:

\footnotetext{
13 Some of the calibrated parameters are adjusted in the dynamic scenario, as explained by van der Mensbrugghe (2006).
} 


$$
\chi_{i, t}=\phi_{i, t}\left(\frac{E_{i, t}}{X_{i, t}}\right)^{\eta_{i}}
$$

where $E_{i, t}$ is exports of commodity $i, X_{i, t}$ is the output of commodity $i, \phi_{i, t}$ is a shift parameter, and $\eta_{i}$ is the elasticity of productivity with respect to openness. The parameter $\phi_{i, t}$ is calibrated in the baseline scenario so that the trade-sensitive portion of sectoral productivity is a constant share of total productivity. ${ }^{14}$

The four types of taxes included in the model consist of commodity, production, income and trade taxes, where the latter include both tariffs and export taxes. Whereas commodity and production taxes are held constant throughout the simulation period, the marginal income tax rate adjusts continuously to maintain a given government budget surplus or deficit.

In keeping with the final implementation of the Uruguay Round, tariff and export tax rates are lowered during the 2001-2005 period. Since the Agreement on Textiles and Clothing (ATC) provides for a phasing out of import quotas on textiles and apparel, these changes are also incorporated in the baseline. In addition, the analysis incorporates the tariff rates called for under the terms for the accession of China and Taiwan to the WTO. Finally, the effects of ASEAN FTA (AFTA) are also incorporated in the baseline scenario, such that bilateral tariffs and export taxes/subsidies among the ASEAN member states are completely removed by 2015 .

Initial sectoral tariff rates for China, Japan, Korea, Singapore, other ASEAN countries, India and Australia/New Zealand in 2001 are summarized in Table 2. There are striking differences in the tariff structures across countries/regions. In Japan and Korea the extraordinarily high tariff rates on rice (825\% and 929\%, respectively) particularly stand out. The tariff rates in a number of other agricultural products, including wheat

\footnotetext{
14 Openness has been linked to increased productivity via three main channels. These consist of the imports of technology-intensive intermediate inputs (for example fertilizers in agriculture), imports of capital goods, and export market penetration. The latter effect can arise because of the higher standards required to access and penetrate foreign markets, relative to those prevailing at home. The expansion of sales to foreign markets can also create scale economies. There is considerable empirical work aimed at ascertaining the extent to which each one of these different channels operates. For example, Das et al. (2007) have explored some firm-level characteristics of export supply responses. The analysis of the links between productivity and trade openness, formulated by de Melo and Robinson (1992), as well as by Dessus et al. (1999), is in many respects similar to that proposed here.
} 
(aggregated to other crops), beef, dairy products and sugar (all of which are aggregated into food products), are also very high in these two countries. In manufacturing the tariff rates on textiles and apparel are relatively high. However, for the other products, tariff rates in Japan are very low, while those in Korea are under $10 \%$.

Singapore is duty free with the exception of alcohol and tobacco, both of which are aggregated into food products. In contrast, India is highly protected with $30 \%$ or higher tariff rates on many product categories. For food products the rate of $76.2 \%$ dwarfs those for Japan and Korea, which initially stand at $24.5 \%$ and $24.7 \%$, respectively. In China and other ASEAN countries, a number of products, including some agricultural products and motor vehicles, are highly protected. Finally, Australia and New Zealand's tariff rates are generally low with the exception of textiles, apparel and motor vehicles.

\subsection{Policy Scenarios}

The economic implications of two proposed free-trade initiatives are to be examined here. Specifically, these two integration cases consist of (1) ASEAN+3 FTA (entailing free trade among ASEAN, China, Japan and Korea) and (2) ASEAN+6 FTA (involving free trade among ASEAN, China, Japan, Korea, India, Australia and New Zealand), for the following four interrelated and nested scenarios:

Scenario 1: The FTA members remove bilateral tariffs and export taxes/subsidies (except rice) over the period 2008-2015. The sector-specific productivity factors capturing the impact of openness, $\chi_{i, t}$, are fixed at the baseline levels.

Scenario 2: A 2.5\% reduction in frictional trade costs among the FTA members over the period 2008-2015 is introduced under Scenario 1, while the sector-specific productivity factors related to the degree of openness, $\chi_{i, t}$, are, again, fixed at the baseline levels.

Scenario 3: The sector-specific productivity factors related to the degree of openness $\left(\chi_{i, t}\right)$ are now endogenously determined, in keeping with equation (2), while maintaining the other assumptions of scenario 2.

Scenario 4: A 10\% reduction in the trade and transport margin over the period 2008-2015 for the FTA members is incorporated in scenario 3. 
In both of the policy experiments, bilateral tariffs and export taxes/subsidies in all the sectors except rice are gradually removed among the FTA member countries over the 2008-2015 period. Rice is excluded from this tariff liberalization process, because Japan and Korea have strongly resisted liberalization of this politically sensitive sector in all the FTAs that they have signed so far. Hence, it is considered here to be extremely unlikely that these two countries would concede to a region-wide FTA involving free trade in this historically protected sector. ${ }^{15}$ For both FTA experiments it is assumed that frictional trade costs, such as administrative barriers and trade-related risks would be reduced by $2.5 \% .{ }^{16}$ Finally, in scenarios 3 and 4, the elasticities of productivity in relation to the degree of openness, $\eta_{i}$, are set equal to values of 1.5 and 2.0 in, respectively, agriculture and all other sectors.

Clearly, there are certain uncertainties regarding the values of the elasticities of productivity with respect to openness, the extent of reductions in frictional trade costs, as well as concerning the trade and transport margin resulting from regional integration. Accordingly, a sensitivity analysis on the welfare effects is conducted in an appendix. This investigation indicates that, even though certain results are sensitive to the key parameter values, the range of changes in welfare is within a reasonable bound.

\section{Empirical Findings}

\subsection{Welfare Effects of FTAs}

For the two FTA experiments and under the four policy scenarios, the welfare implications will be assessed here in terms of deviations in equivalent variations (EV) from the baseline in 2015. Certain key results are summarized in Tables 3 and 4. Under the ASEAN+3 FTA policy experiment, economic welfare of China, Japan, Korea,

\footnotetext{
15 In a preliminary study, Lee (2008) estimates the costs of excluding rice, as well as those of excluding all agricultural products, from various FTA scenarios involving Japan. Under the ASEAN+6 FTA, for example, the costs of excluding rice, in terms of percent reductions in welfare gains, are found to be highest in Japan (28\%), followed by Korea (19\%), China (10\%) and ASEAN (9\%). The effects on Australia, India and New Zealand are found to be negligible.

16 Keuschnigg and Kohler (2002) and Madsen and Sorensen (2002) consider a 5\% reduction in real costs of trade between the EU-15 and Central and East European countries. However, a smaller reduction in these costs is invoked here, since the reductions in technical barriers are expected to be negligible for FTAs in East Asia, as compared with those under EU enlargement.
} 
Singapore and other ASEAN countries increases only slightly under scenario 1. While trade between these member countries would increase significantly, the trade flows between the integrating countries and the rest of the world decline. Indeed, there are extremely small welfare losses, which would be incurred either by the recently expanded EU area of 27 countries, comprising then EU-15 and 12 new EU member states, or North America. These overall findings are compatible with the suggestion that trade creation effects dominate those of trade diversion.

In terms of percentage deviations from the baseline, Singapore's welfare gain of $0.29 \%$ exceeds that of the other ASEAN countries, which experience an increase of $0.07 \%$. This finding may initially appear surprising, since consumers in countries with higher initial tariff rates generally are expected to benefit more from regional integration. Nonetheless, this result is clearly driven by the Armington assumption of nationally differentiated products, which implies that each country has a monopoly in the market for its exports. ${ }^{17}$ Indeed, following regional integration Singapore's terms of trade improve, while those for other ASEAN economies deteriorate, dominating other welfare effects for Singapore.

When a $2.5 \%$ reduction in trade costs among the ASEAN+3 countries is added, under scenario 2, the magnitudes of welfare gains for the FTA members are amplified considerably. Principally, this is a trade creating policy initiative, since lower administrative and technical barriers facilitate trade by generating greater intra-regional market access. Furthermore, while there are slight welfare losses for the EU and North America, the net consequences for world welfare are an increase to $0.13 \%$ from the $0.03 \%$ gain in the previous policy simulation.

In the next two scenarios, the sector-specific productivity levels actually respond to changes in the sectoral export-output ratios. While a comparison between the results for scenarios 3 and 2 points to welfare gains for all four member regions, as a result of endogenizing $\chi_{i, t}$, there are substantial variations across regions. Notably, the relatively small gains for Japan, Korea, Singapore and other ASEAN are dwarfed by those for China, where the welfare gain increases more than threefold, rising from $0.77 \%$ to $2.61 \%$. A

17 Brown (1987) shows that monopoly power implicit in national product differentiation is the source of strong terms of trade effects resulting from tariff changes in Armington-type models. 
plausible explanation might be that increases in export-output ratios for many products are far greater for China than for the other envisaged FTA members, but further investigation is called for in order to better understand the specific mechanisms characterizing the nature of the linkages between openness and productivity.

For the EU and North America the welfare loss decreases in scenario 3, in comparison with scenario 2, since export-output ratios increase slightly in several sectors, which are principally driven by heightened EU and U.S. exports to China. These asymmetric implications appear directly linked to the unique welfare and real GDP gains for China, which, as previously noted, are significantly larger when productivity is treated as endogenous. Overall, the global welfare gain doubles from $0.13 \%$ to $0.26 \%$, when comparing scenarios 2 and 3.

Under scenario 4, it is hypothesized that increased competition within the integrating region leads to a significant reduction in the trade and transport margin, specifically by $10 \%$ over the period 2008-2015, as compared with the baseline. The associated welfare gains for the FTA partners are striking, almost uniformly doubling for China, Japan, Korea and Singapore, while more than tripling for other ASEAN countries. The welfare for the EU and North America is only marginally affected between scenarios 3 and 4, changing by 0.01-0.02 percentage point.

As shown in Table 4, with the ASEAN+6 FTA policy experiment, where India, Australia and New Zealand join in the integrating process, economic welfare of all member countries, except India, increases under scenario 1. India's welfare loss largely stems from a sharp decline in its terms of trade after the elimination of tariffs. In this regard, as already noted, India's ex ante tariff rates in 2001 are substantially higher than for the other envisaged FTA members. Another explanation for India's unique welfare loss is that the ex ante value of the country's imports from other FTA countries is much lower, accounted for only $28 \%$ in 2001. In contrast, imports from the integrating region represent 53\% for China, Singapore and other ASEAN, 42\% for Korea and Australia/New Zealand, and 39\% for Japan. Moreover, India's trade has been historically much more oriented to the EU and North America, as reflected by export shares of the two regions, which 
constituted, respectively, $30 \%$ and $23 \%$ in $2001 .{ }^{18}$ Thus, the initially smaller trade shares with the other ASEAN+6 economies limits the country's potential gains, since the positive impact of the predicted increases in intra-FTA trade do not offset the terms of trade loss. A generic insight is that the welfare implications of regional integration for specific countries entail potentially significant hysteresis effects, where the path dependency is critically defined by initial configurations of trade costs and associated flows. Nonetheless, India would experience only minor losses when frictional trade costs are reduced. Furthermore, India actually experiences significant welfare gains when sectoral productivity levels are endogenized and, then, the trade and transport margin is lowered. Indeed, India's welfare increases under scenarios 3 and 4 to respectively $0.75 \%$ and $1.4 \%$ in 2015 , as compared with the baseline.

The relative welfare consequences of the two FTA policy exercises can now be compared. Under scenario 1 an expanded FTA agreement generates amplified welfare changes for the participating countries. These principally constitute gains except for India, where, for the reasons stated above, the welfare loss becomes more pronounced. ${ }^{19}$ Under scenarios 2 through 4, the differences in the welfare changes between the ASEAN+3 and +6 FTAs are generally less pronounced for the initial set of countries participating in the smaller FTA. Accordingly, China, Japan, Korea and Singapore all experience either relatively small reductions in welfare gains or are hardly affected by the expansion to include Australia, India and New Zealand. More specifically, with India's entry into the regional trading bloc, China's exports of light manufactures (such as textiles, apparel and other manufactures) to ASEAN, Japan and Korea, as well as to the world, fall, thereby offering an explanation for a slightly lower welfare gains for China under the ASEAN+6 FTA proposal. In the case of the more restricted integration proposal, there is a large growth in the exports of both Japan and Korea to China, thereby greatly benefiting the former two countries. With expanded integration inclusive of India, Australia and New Zealand, some of Chinese imports from Japan, Korea and Singapore are projected to be replaced by the three additional member countries. This can explain why the welfare gains

\footnotetext{
18 In the same year India's imports from the EU and North America accounted for $28 \%$ and $14 \%$ of its total imports.

${ }^{19}$ For Australia/New Zealand there is a reversal of the welfare effects, with positive results under the ASEAN+6 FTA, instead of a loss in the more restricted membership case.
} 
for these three countries appear to be more limited under scenarios 2 through 4, when the integration club also encompasses Australia, India and New Zealand. Finally, instead of encountering welfare losses, as suggested by the first policy experiment, the welfare enhancing effects for Australia and New Zealand of membership in an expanded FTA are relatively large, ranging from $1.07 \%$ in the initial scenario to $2.96 \%$ for the final one. Presumably, this is in line with the idea that relatively productive, but small, economies can particularly gain from access to substantially expanded markets, through regional integration, particularly when such an area includes certain less efficient competing industries abroad.

\subsection{Trade Flow Effects for Selected Products}

In this sub-section, the trade flow effects of regional integration involving ASEAN+6 countries are assessed for eight selected products under the assumptions invoked under the fourth scenario. ${ }^{20}$ Accordingly, sectoral productivity levels are endogenously determined, while it is assumed that there are reductions of $2.5 \%$ in frictional trade costs and a $10 \%$ decrease in the trade and transport margin among the member states over the period 20082015. Table 5 reports findings for three aggregate regions (the ASEAN+6 countries, EU27, and North America), along with the world as a whole, again expressed in terms of percent deviations from the baseline in 2015.

For four products, specifically other crops (excluding rice), processed food, textiles and apparel, exports to the ASEAN+6 FTA area from the EU and North America decline substantially, as a result of the regional economic integration. It should be noted that East Asia constitutes a relatively important international market for North American farmers and food producers, particularly those in the United States. ${ }^{21}$ Consequently, there is also a substantial reduction in overall North American exports to the world as a whole. A similar finding applies in the case of processed food. For the other crop sector, there appears to be considerable scope for trade diversion. Specifically, exports to the Japanese and Korean markets from North America are predicted to be replaced by intra-regional

\footnotetext{
${ }^{20}$ Regional trade integration among the ASEAN+3 countries yields qualitatively similar results and are, accordingly, not reported separately.

21 More specifically, according to the GTAP database used in this study, in 2001, 34\% of North American exports of other crops were shipped to East Asia, while 30\% of food products were exported there. In contrast, only 2.5\% of EU exports of other crops were destined for East Asia in that same year.
} 
suppliers from not only Australia/New Zealand, but also China and other ASEAN, where the latter country and region are currently net importers. While there are comparable sharp falls in the exports from the EU of other crops and processed food to ASEAN+6, total European exports are much less affected than in the case of North America, given the much lower exports shares that the integrating region represents for EU suppliers.

The scenario for exports of textiles and apparel from the EU and North America differ from those just discussed for crops and processed food. Although the envisaged FTA for the ASEAN+6 countries generates a significant fall in their exports in the former sectors, the negative impact on overall exports to the world is relatively limited, given that European and North American exports to the FTA zone are initially less than $10 \%$ of both regions' global exports in textiles and apparel. Furthermore, in light of the high degree of global competitiveness of producers from China, India and other ASEAN countries, trade diversion, if any, would likely be quite minimal.

For iron and steel, machinery, electronic equipment and motor vehicles, the reductions in EU and North American exports to Asia are projected to be more moderate. This is principally because the initial tariff rates in ASEAN+6 countries are relatively low, with the exception of the motor vehicle sector, where European and North American producers face substantial tariff barriers in the Chinese, Indian, and other ASEAN markets. Although not shown in Table 5, EU and North American exports to ASEAN+6 are predicted to decrease by less than $2 \%$ in livestock, natural resources, nonferrous metal, metal products and other manufactures, while increasing somewhat in services. Overall, the trade implications of regional integration, comprising ASEAN+6, appear rather minimal for a large number of products.

\subsection{Sectoral Output Effects}

Estimates of the impact of regional integration, following an ASEAN+6 FTA initiative, are provided for the 22 sectors under scenario 4 . The expected changes are again expressed in percent deviations from the baseline in 2015. Since frictional trade costs and the trade and transport margin is reduced by the same rates in all the sectors, the differences in the initial tariff rates across sectors play a critical role in determining the direction of the adjustments in sectoral output. Other key factors, determining the magnitude and direction of output adjustments for each product category, include the 
import-demand ratio, the export-output ratio, the share of each imported intermediate input in total costs, and the elasticity of substitution between domestic and imported products. ${ }^{22}$

In every country/region, the change in rice output is rather small because the tariff rate on this commodity is assumed to be fixed for all of the scenarios. By contrast, output adjustments in other crops are considerable in a number of countries. Specifically, output of other crops in Korea and Japan is predicted to contract by $68.3 \%$ and $13.3 \%$, respectively, whereas it would increase by $33.3 \%$ in Australia/New Zealand, $15.1 \%$ in China, and 3.5\% in other ASEAN. Although the effect on the EU is very small, North America's output of other crop is expected to fall by $4.1 \%$. Furthermore, since North America is the largest producer of other crops among the 12 countries/regions, it is the area the most impacted by regional integration in Asia.

Among manufacturing sectors, output adjustments are the largest for food products, textiles and apparel, and, to a lesser extent, motor vehicles. This is to be expected, since, aside from Singapore, the initial tariff rates for these product groups are generally higher than for most other products. The contraction of processed food output in Japan and India is largely caused by a sharp increase in imports from other FTA members, following the removal of relatively high tariffs. Yet, even though the initial tariff rates for Korea and the other ASEAN countries in processed food are also high, output in these countries actually expands. An explanation for Korea is that the removal of the $188 \%$ tariff rate on other crops would substantially reduce the cost of intermediate inputs (notably for wheat, oil seeds and sugar), which are used to produce processed food, thereby reducing domestic price and increasing demand. Accordingly, the associated expansion of output dominates other contractionary effects. To a lesser extent, similar mechanisms also apply for other ASEAN. For both Korea and other ASEAN, imports from non-ASEAN+6 countries contract, because the ratio of domestic to import prices falls. In addition, since computations based on the GTAP database reveal that roughly $50 \%$ of India's imports of

\footnotetext{
22 A sector with a larger import-demand ratio generally suffers from proportionately larger output contraction through greater import penetration, when initial tariff levels are relatively high. In contrast, a sector with a higher export-output ratio typically experiences a larger extent of output expansion, as a result of the removal of tariffs in the partner countries. The share of imported intermediate inputs in the total cost of a downstream industry (e.g., the share of imported textiles in the cost of the apparel industry) would evidently affect the magnitude and direction of output adjustments in the latter sector. Finally, the greater the values of substitution elasticities between domestic and imported products, the greater the sensitivity of the import-domestic demand ratio to changes in the relative price of imports, thereby magnifying the effects of regional integration.
} 
food products come from the ASEAN countries other than Singapore, the removal of India's $76 \%$ tariff rate on food products would substantially expand imports from those countries. Finally, output of processed food in Australia/New Zealand would expand sharply, due to large increases in these two countries' exports to Asia.

The initial tariff rates on textiles and apparel are relatively high in the ASEAN+6 countries, except for Singapore. While China is not only the largest exporter and importer of textiles in Asia, it is also the largest exporter of apparel in the world, while Japan is the largest importer of apparel in Asia. At the same time, Japan and Korea's textile exports to China constitute, respectively, over $50 \%$ and $30 \%$ of their textile exports to the world. Following integration, textile exports from both Japan and Korea to other parts of the region, particularly to China, increase dramatically. ${ }^{23}$ Consequently, textile output in the former two countries increases. However, the percent increase is more substantial for Korea, due to a much higher export-output ratio of 0.62 , in contrast to the 0.30 value for Japan. While apparel output expands in China, Korea and India, reverse tendencies apply for the other member countries including ASEAN. ${ }^{24}$ Indeed, particularly large reductions are anticipated for Australia/New Zealand and Japan.

The output changes in machinery and electronic equipment appear to be somewhat counter-intuitive in light of the comparative advantage of Japan and Korea for these products in relation to the other FTA members. However, as noted by Ando and Kimura (2005a) and Kimura (2006), international fragmentation has dramatically developed in the machinery sector in East Asia since the 1990s. ${ }^{25}$ Paralleling this development is a significant rise, across East Asia, in the shares of parts and components in both exports and imports of machinery. More specifically, over the 1990-2003 period, intra-East Asian exports of machinery parts and components increased by 452\%, which accounted for about a half of intraregional export growth, as recognized by Ando and Kimura (2005b).

\footnotetext{
23 The substantial increase in China's textile imports principally arises from a significant expansion of apparel production.

24 This result is consistent with Lee and Mensbrugghe's (2008) finding that for ASEAN the revealed comparative advantage (RCA) index of apparel is near the top of the ranking under global trade liberalization. Nonetheless, the RCA raking of apparel falls significantly under the FTAs that include China and/or Korea.

25 In these studies, the machinery sector includes electric machinery, which comprises electronic equipment.
} 
Since machinery, including electronic equipment, is the largest export product category in most East Asian countries, even though they are at different development stages, the results shown in Table 6 are quite plausible.

While the significant reduction in output of other crops in North America has already been noted, the only other products that experience more than $1 \%$ reductions in output in either the EU or North America occur in the case of textiles and apparel for the EU-15. In contrast, the latter sectors are hardly affected in the new EU member states, given that only about one percent of their exports of textiles and apparel is shipped to Asia, while fully $73 \%$ of textile and $85 \%$ of apparel exports are destined for EU-15. ${ }^{26}$ When productivity is positively correlated with economic openness, while the trade and transport margin is assumed to fall, a number of manufacturing sectors in the EU and North America potentially experience relatively limited output expansions, as a result of postulated regional integration in Asia. Furthermore, the overall sectoral effects in the EU and North America are essentially somewhat favorable, with the notable exception of crops other than rice in North America, principally impacting the United States.

\section{Conclusion}

A dynamic CGE model, based on the LINKAGE model developed at the World Bank, has been used to quantify the effects of regional integration in Asia on economic welfare, trade flows and sectoral output of FTA member and non-member countries/regions. An initial regional policy integration experiment, comprising ASEAN countries, China, Korea and Japan, designated as ASEAN+3 FTA, has been expanded to consider an ASEAN+6 FTA paradigm, which also includes Australia/New Zealand and India. Each experiment has assessed the effects of the FTA formations over a 2008-2015 time horizon under alternative hypotheses regarding the extent of integration. Novel features of the analysis include allowing for both trade facilitation and endogenously determined productivity levels, which are assumed to be positively correlated with economic openness. More specifically, for each experiment four different nested scenarios have been considered, starting with the removal of bilateral tariffs and export

\footnotetext{
26 In sharp contrast, Lee and van der Mensbrugghe (2004) found that EU enlargement would result in $4.5 \%$ and $2.2 \%$ reductions in apparel output in, respectively, ASEAN and China, along with $2.6 \%$ and 1.6\% declines in textile output in ASEAN and Asian NIEs, as compared with the baseline in 2015.
} 
taxes/subsidies, except for the rice sector. Subsequently, reductions in frictional trade costs have then been examined, while again assuming that sector-specific productivity factors related to degrees of openness are fixed. In two final scenarios, these productivity factors are first endogenized to depend on the degree of openness, while the incremental effects of lowering trade and transport margins are also assessed.

The empirical research findings suggest that, in the absence of trade facilitation and a linkage between productivity and openness, the welfare effects of the initial tariff removal among the FTA members are actually quite small. In sharp contrast, once these latter effects are incorporated into the CGE analysis, the welfare gains of the member countries become significantly larger, ranging from $0.7 \%$ in Japan to $5.9 \%$ in Singapore under the ASEAN+6 FTA experiment. Yet, the welfare effects on the EU and North America are found to be negligible. Nonetheless, in the case of the more extensive of the two Asian FTAs, the welfare of India actually declines under some scenarios. The latter, rather distinctive outcomes appear to reflect hysteresis effects, linked to very high existing tariff levels in a number of key sectors in India, as well as traditionally limited trade flows with East Asia, relative to those with industrialized and developing countries elsewhere.

Exports of other crops and processed food from the EU and North America to the ASEAN+6 FTA area have been projected to decline substantially, as a result of regional integration. Since East Asia constitutes a relatively important international market for North American farmers and food producers, overall North American exports of these products to the world as a whole are also subject to substantial reductions. In particular, the predicted output of other crops in North America decreases by 4.1\%, as compared with the baseline in 2015. Nonetheless, for the rest of product categories in the EU and North America, changes in output caused by Asian regional integration are all less than $1.5 \%$.

A valuable but challenging extension of the paper would be to endogenize FDI flows involving Asian countries. Such an analysis would need to consider how the interrelation between alternative categories of cost-enhancing and market-seeking FDI potentially impact not only trade flows, but also rates of technological diffusion and, thereby, the structure and international competitiveness of Asian industry. As previously noted, many Asian countries are characterized by relatively high growth rates and/or low efficiency wages, while a surge in FDI inflows, notably in China, over the past two decades also appears closely interlinked with changes in intra and extra-regional trade 
patterns. Indeed, not only have MNEs from the EU, Japan, the United States and other industrialized countries undertaken extensive outsourcing and delocalization in many Asian economies, but also there has been a remarkable upswing of intra-regional Asian FDI flows, involving other source countries. Further regional economic integration in Asia, particularly if accompanied by investment liberalization, could induce significant additional build-ups of FDI flows involving FTA members as source and host countries. Yet, a significant impediment to undertaking such an extension of the analysis to allow more explicitly for the role of FDI is that the data on bilateral FDI flows by sector are not readily available for many Asian countries. However, it remains a worthwhile long-term project to estimate such data and extend the model to allow for the impact of endogenously determined FDI on the FTA members and outside economies.

A final methodological issue points to certain generic limitations to investigations, aimed at assessing the effects of regional integration, which, as in the present research, are inherently based on relatively aggregate existing data and economic relations. As witnessed by the European integration process, notably following the Single European Act and Treaty of Maastricht, profound economic integration is inherently multidimensional. Notably, regional integration can entail substantial transformations in national and pannational governance and market structures, reflecting redefined legal, political and economic environments. Such changes can potentially alter a wide range of microeconomic incentive mechanisms, along with the determinants of individual agents' performance. As such, ex post model simulations that do not explicitly capture such phenomena risk generating biased economic projections, given that aggregate model simulations are calibrated on ex ante statistics and economic relations, which, to varying degrees, may no longer apply. 


\section{Appendix: Sensitivity Analysis}

Simulation results can be sensitive to chosen model parameter values. In this section, we conduct a sensitivity analysis on the welfare effects by varying the extent to which frictional trade costs are reduced $(\lambda)$, the elasticity of productivity with respect to openness $(\eta)$, and the magnitude of reduction in the trade and transport margin $(\zeta)$. Specifically, we conduct the following ten sets of sensitivity tests:

1) $\lambda=2.5 \%, \eta=0, \zeta=0$

2) $\lambda=5 \%, \eta=0, \zeta=0$

3) $\lambda=2.5 \%, \eta=(0.75,1.0), \zeta=0$, where the first value of $\eta(0.75)$ is $\eta$ for agricultural sectors and the second value of $\eta(1.0)$ is $\eta$ for all other sectors.

4) $\lambda=2.5 \%, \eta=(1.5,2.0), \zeta=0$

5) $\lambda=5 \%, \eta=(0.75,1.0), \zeta=0$

6) $\lambda=5 \%, \eta=(1.5,2.0), \zeta=0$

7) $\lambda=2.5 \%, \eta=(0.75,1.0), \zeta=10 \%$

8) $\lambda=2.5 \%, \eta=(0.75,1.0), \zeta=20 \%$

9) $\lambda=5 \%, \eta=(1.5,2.0), \zeta=10 \%$

10) $\lambda=5 \%, \eta=(1.5,2.0), \zeta=20 \%$

The results of the sensitivity analysis on the welfare effects under the ASEAN+3 FTA are summarized in Table A.1. When the value of $\lambda$ (the extent to which frictional trade costs are reduced) doubles while the values of $\eta$ and $\zeta$ are held fixed at zero, the welfare level of many member countries (e.g., China, Singapore and other ASEAN) roughly doubles, while that of Japan and Korea increases by 50-60 percent [columns (1) and (2)]. However, if the value of $\lambda$ doubles when elasticity values of productivity in relation to openness of $\eta=1.5$ in agricultural sectors and $\eta=2.0$ in all other sectors are assumed, the welfare level of all member countries less than doubles [columns (4) and (6)]. Thus, while an increase in the value of $\lambda$ has similar effects as reductions in the tariff rates 
on all commodities by the same percentage points, the welfare results are also affected by the initial values of $\eta$, particularly for China.

In (1), (3) and (4), as well as in (5) and (6), only the value of $\eta$ is changed while the values of $\lambda$ and $\zeta$ are held constant. The results suggest that China's welfare is greatly affected by the changes in the value of $\eta$. By contrast, other regions' welfare is rather insensitive to the changes in this parameter. This implies that the export/output ratio is little affected by the ASEAN+3 FTA with the exception of China.

Finally, the rate of reduction in the trade and transport margin, represented by the parameter value of $\zeta$, is doubled between (7) and (8), as well as between (9) and (10). A further reduction in the trade and transport margin benefits every member country. Specifically, if $\zeta$ doubles from $10 \%$ to $20 \%$, when parameter values of $\lambda=2.5 \%$ and $\eta=$ 0.75 are assumed in agricultural sectors and $\eta=1.0$ in all other sectors, the welfare gains of the member countries increase by roughly $30 \%$ in all member countries. When $\lambda=5 \%$ and $\eta=1.5$ in agricultural sectors and $\eta=2.0$ in all other sectors, the welfare gains of the member countries increase by $20-25 \%$.

Considering relatively large differences in the values of $\lambda, \eta$ and $\zeta$ between (1) and (10), the sensitivity of the welfare results is within a reasonable range. However, the sets of the parameter values (8)-(10) might be rather unrealistic because the welfare gains for Singapore in excess of 8\% under the ASEAN+3 FTA are extremely unlikely. 


\section{References}

Anderson, K., W. Martin, and D. van der Mensbrugghe, 2006. Market and welfare implications of Doha reform scenarios. In: K. Anderson and W. Martin (Eds.), Agricultural Trade Reform and the Doha Development Agenda. New York and Washington, DC: Palgrave Macmillan and World Bank.

Ando, M. and F. Kimura, 2005a. The formation of international production and distribution networks in East Asia. In: T. Ito and A. K. Rose (Eds.), International Trade in East Asia. Chicago: University of Chicago Press.

Ando, M. and F. Kimura, 2005b. Global supply chains in machinery trade and sophisticated nature of production/distribution networks in East Asia. KUMQRP Discussion Paper No. 2005-15. Tokyo: Keio University.

Armington, P., 1969, A theory of demand for products distinguished by place of production. IMF Staff Papers 16, 159-178.

Asian Development Bank, 2008a. Emerging Asian Regionalism. Manila: Asian Development Bank.

Asian Development Bank, 2008b. How to Design, Negotiate, and Implement a Free Trade Agreement in Asia. Manila: Asian Development Bank.

Bchir, H., Y. Decreux, J-L. Guérin, and S. Jean. 2002. MIRAGE, A computable general equilibrium model for trade policy analysis. CEPII Working Paper No. 2002-17. Paris: Centre d'Études Prospectives et d'Informations Internationales (CEPII).

Brown, D. K., 1987. Tariffs, the terms of trade, and national product differentiation. Journal of Policy Modeling 9, 503-526.

Das, S., M. J. Roberts, and J. R. Tybout, 2007. Market entry costs, producer heterogeneity, and export dynamics. Econometrica 75, 837-873.

de Melo, J. and S. Robinson,1992. Productivity and externalities: Models of export-led growth. Journal of International Trade \& Economic Development 1, 41-68.

Dee, P., 2007. East Asian economic integration and its impact on future growth. World Economy 30, 405-423.

Dervis, K., J. de Melo and S. Robinson, 1982. General Equilibrium Models for Development Policy. Cambridge: Cambridge University Press.

Dessus, S., K. Fukasaku, and R. Safadi, 1999. Multilateral tariff liberalization and the developing countries. OECD Development Centre Policy Brief, No. 18. Paris: OECD.

Dimaranan, B. V. (Ed.), 2006. Global Trade, Assistance, and Production: The GTAP 6 Data Base. West Lafayette: Center for Global Trade Analysis, Purdue University.

Hertel, T. W. (Ed.), 1997. Global Trade Analysis: Modeling and Applications. Cambridge: Cambridge University Press. 
Ianchovichina, E. and R. McDougall, 2000. Theoretical structure of dynamic GTAP. GTAP Technical Paper No. 17. West Lafayette: Center for Global Trade Analysis, Purdue University.

Kawai, M. and G. Wignaraja, 2007. ASEAN+3 or ASEAN+6: Which way forward? ADB Institute Discussion Paper No. 77. Tokyo: ADB Institute

Keuschnigg, C. and W. Kohler, 2002. Eastern enlargement of the EU: How much is it worth for Austria? Review of International Economics 10, 324-342.

Kimura, F., 2006. International production and distribution networks in East Asia: Eighteen facts, mechanics, and policy implication. Asian Economic Policy Review 1, 326-344.

Lee, H., 2008. Japan's agricultural protection and the implications for its FTA strategies. Paper presented at the 11th International Convention of the East Asian Economic Association, Manila, 15-16 November.

Lee, H. and D. van der Mensbrugghe, 2004. EU enlargement and its impacts on East Asia. Journal of Asian Economics 14(6), 843-860.

Lee, H. and D. van der Mensbrugghe, 2005. Interactions between foreign direct investment and trade in a general equilibrium framework. Paper presented at the ADB Experts' Meeting on Long-term Scenarios of Asia's Growth and Trade, Asian Development Bank, Manila, 10-11 November.

Lee, H. and D. van der Mensbrugghe, 2008. Regional integration, sectoral adjustments and natural groupings in East Asia. International Journal of Applied Economics 5(2), 57-79.

Lluch, C., 1973. The extended linear expenditure system. European Economic Review 4, 21-32.

Löfgren, H., R. L. Harris and S. Robinson, 2002. A Standard Computable General Equilibrium (CGE) Model in GAMS. Microcomputers in Policy Research 5. Washington, DC: International Food Policy Research Institute.

Madsen, A. D. and M. L. Sorensen, 2002. Economic consequences for Denmark of EU enlargement. Paper presented at the International Conference on Policy Modeling, Brussels, 4-6 July.

Martin, W. and D. Mitra, 2001. Productivity growth and convergence in agriculture and manufacturing. Economic Development and Cultural Change 49, 403-422.

Owen, R. F., 2001. Widening and deepening of ASEAN: Lessons from the European experience. Chulalongkorn Journal of Economics, 13(3), 269-319.

Park, I., 2006. East Asian regional trade agreements: Do they promote global free trade? Pacific Economic Review 11, 547-568.

Plummer, M. G., 2007. Best practices in regional trading agreements: An application to Asia. World Economy 30, 1771-1796.

Samuelson, P. A., 1952. The transfer problem and transport costs: The terms of trade when impediments are absent. Economic Journal 62, 278-304. 
Scollay, R. and J. Gilbert, 2001. New Subregional Trading Arrangements in the AsiaPacific. Washington, DC: Institute for International Economics.

Urata, S. and K. Kiyota, 2005. The impacts of an East Asia FTA on foreign trade in East Asia. In: T. Ito and A. Rose (Eds.), International Trade in East Asia, Chicago: University of Chicago Press.

van der Mensbrugghe, D., 2005. LinKage Technical Reference Document: Version 6.0. Washington, DC: World Bank.

van der Mensbrugghe, D., 2006. Estimating the benefits: Why numbers change. In: R. Newfarmer (Ed.), Trade, Doha and Development: A Window into the Issues. New York and Washington, DC: Palgrave Macmillan and World Bank.

World Bank, 2000. Trade Blocs. New York and Washington, DC: Oxford University Press and World Bank.

World Bank, 2005. Global Economic Prospects: Trade, Regionalism, and Development. Washington, DC: World Bank.

World Trade Organization, 1995. Regionalism and the World Trading System. Geneva: World Trade Organization.

Zhai, F., 2006. Preferential trade agreements in Asia: Alternative scenarios of "hub and spoke.” ERD Working Paper Series No. 83. Manila: Asian Development Bank. 
Table 1: Regional and sectoral aggregation

A. Regional aggregation

\begin{tabular}{ll}
\hline Country/region & Corresponding economies/regions in the GTAP database \\
\hline China & China, Hong Kong \\
Japan & Japan \\
Korea & Korea \\
Taiwan & Taiwan \\
Singapore & Singapore \\
Other ASEAN & Indonesia, Malaysia, Philippines, Thailand, Vietnam, rest of Southeast Asia \\
India & India \\
Australia/New Zealand & Australia, New Zealand \\
North America & United States, Canada, Mexico \\
EU-15 & Austria, Belgium, Denmark, Finland, France, Germany, Great Britain, \\
& Greece, Ireland, Italy, Luxembourg, Netherlands, Portugal, Spain, Sweden \\
New EU members & 12 new EU member states since 2004 \\
Rest of world & All the other economies/regions \\
\hline
\end{tabular}

B. Sectoral aggregation

\begin{tabular}{ll}
\hline Sector & Corresponding commodities/sectors in the GTAP database \\
\hline Rice & Paddy rice, processed rice \\
Other crops & Wheat, cereal grains nec, vegetables and fruits, oil seeds, sugar cane and \\
& sugar beet, plant-based fibers, crops nec \\
Livestock & Bovine cattle, sheep and goats, animal products nec \\
Natural resources & forestry, minerals, mineral products \\
Fossil fuel & Coal, oil, gas \\
Food products & Fishing, meat products, dairy products, other food products, beverages and \\
& tobacco products \\
Textiles & Textiles \\
Apparel & Wearing apparel and leather \\
Wood and paper & Wood products, paper products and publishing \\
Petroleum products & Petroleum and coal products \\
Chemical products & Chemical, rubber and plastic products \\
Iron and steel & Iron and steel \\
Nonferrous metal & Nonferrous metal \\
Metal products & Fabricated metal products \\
Machinery & Machinery and equipment \\
Electronic equipment & Electronic equipment \\
Motor vehicles & Motor vehicles and parts \\
Other transport equip. & Other transportation equipment \\
Other manufactures & Manufactures nec \\
Construction and utilities & Construction, public utilities \\
Trade and transport & Trade, sea transport, air transport, transport nec \\
Services & Communication, financial services, other services \\
\hline
\end{tabular}

Source: GTAP database, version 6 .

Note: nec $=$ not elsewhere classified. 
Table 2: Initial sectoral tariff rates, 2001 (\%)

\begin{tabular}{|c|c|c|c|c|c|c|c|}
\hline & China & Japan & Korea & Singapore & $\begin{array}{r}\text { Other } \\
\text { ASEAN }\end{array}$ & India & $\begin{array}{r}\text { Australia/ } \\
\text { New Zealand }\end{array}$ \\
\hline Rice & 0.4 & 825.1 & 929.0 & 0.0 & 23.6 & 52.2 & 0.0 \\
\hline Other crops & 54.5 & 27.2 & 188.1 & 0.0 & 12.9 & 28.0 & 0.4 \\
\hline Livestock & 4.3 & 4.0 & 3.7 & 0.0 & 3.6 & 14.2 & 0.0 \\
\hline Natural resources & 4.2 & 0.3 & 4.4 & 0.0 & 7.7 & 16.8 & 3.5 \\
\hline Fossil fuel & 0.0 & 0.0 & 4.0 & 0.0 & 1.0 & 16.8 & 4.4 \\
\hline Food products & 9.8 & 24.5 & 24.7 & 0.5 & 20.4 & 76.2 & 3.2 \\
\hline Textiles & 15.0 & 7.1 & 9.2 & 0.0 & 13.5 & 26.2 & 11.1 \\
\hline Apparel & 4.0 & 10.9 & 9.9 & 0.0 & 14.1 & 27.6 & 16.2 \\
\hline Wood and paper & 6.9 & 1.1 & 4.0 & 0.0 & 7.3 & 22.0 & 3.1 \\
\hline Petroleum products & 6.2 & 1.6 & 5.6 & 0.0 & 4.7 & 16.6 & 0.1 \\
\hline Chemical products & 11.2 & 1.0 & 6.7 & 0.0 & 6.8 & 31.0 & 2.8 \\
\hline Iron and steel & 6.1 & 1.0 & 2.8 & 0.0 & 8.0 & 34.6 & 3.9 \\
\hline Nonferrous metal & 5.1 & 0.4 & 3.9 & 0.0 & 3.8 & 33.1 & 0.9 \\
\hline Metal products & 8.4 & 0.5 & 7.5 & 0.0 & 11.7 & 33.8 & 5.5 \\
\hline Machinery & 10.7 & 0.1 & 6.1 & 0.0 & 5.0 & 25.4 & 3.3 \\
\hline Electronic equipment & 6.9 & 0.0 & 1.1 & 0.0 & 1.5 & 15.1 & 0.8 \\
\hline Motor vehicles & 28.9 & 0.0 & 7.8 & 0.0 & 32.2 & 40.3 & 15.2 \\
\hline Other transport equip. & 3.6 & 0.0 & 1.2 & 0.0 & 11.0 & 18.9 & 0.6 \\
\hline Other manufactures & 6.2 & 1.2 & 9.5 & 0.0 & 8.0 & 34.2 & 3.1 \\
\hline
\end{tabular}

Source: GTAP database, version 6. 
Table 3: Effects on welfare resulting from the ASEAN+3 FTA

(Deviations in equivalent variations from the baseline in 2015)

\begin{tabular}{|c|c|c|c|c|}
\hline Region & Scenario 1 & Scenario 2 & Scenario 3 & Scenario 4 \\
\hline \multicolumn{5}{|c|}{ A. Absolute deviations (US\$ billion in 2001 prices) } \\
\hline China & 2.32 & 17.42 & 58.95 & 102.23 \\
\hline Japan & 5.42 & 12.48 & 13.50 & 28.66 \\
\hline Korea & 4.81 & 9.09 & 10.58 & 19.17 \\
\hline Taiwan & -0.93 & -1.40 & -1.08 & -1.74 \\
\hline Singapore & 0.32 & 3.21 & 3.38 & 7.00 \\
\hline Other ASEAN & 0.52 & 9.77 & 9.88 & 32.01 \\
\hline India & -0.38 & -0.61 & -0.55 & -0.91 \\
\hline Australia/New Zealand & -0.28 & -0.37 & -0.36 & -0.72 \\
\hline North America & -1.21 & -2.22 & -1.59 & -2.39 \\
\hline EU-15 & -0.73 & -1.56 & -0.25 & -1.08 \\
\hline New EU members & -0.02 & -0.03 & 0.01 & 0.08 \\
\hline Rest of world & -0.77 & -1.45 & -3.83 & -5.61 \\
\hline ASEAN+3 countries & 13.39 & 51.97 & 96.29 & 189.07 \\
\hline World & 9.07 & 44.32 & 88.64 & 176.71 \\
\hline \multicolumn{5}{|l|}{ B. Percent deviations } \\
\hline China & 0.10 & 0.77 & 2.61 & 4.53 \\
\hline Japan & 0.14 & 0.33 & 0.36 & 0.76 \\
\hline Korea & 0.75 & 1.41 & 1.65 & 2.99 \\
\hline Taiwan & -0.24 & -0.36 & -0.27 & -0.44 \\
\hline Singapore & 0.29 & 2.96 & 3.10 & 6.45 \\
\hline Other ASEAN & 0.07 & 1.21 & 1.23 & 3.97 \\
\hline India & -0.05 & -0.08 & -0.07 & -0.12 \\
\hline Australia/New Zealand & -0.06 & -0.08 & -0.08 & -0.15 \\
\hline North America & -0.01 & -0.02 & -0.01 & -0.02 \\
\hline EU-15 & -0.01 & -0.02 & 0.00 & -0.02 \\
\hline New EU members & 0.00 & -0.01 & 0.00 & 0.02 \\
\hline Rest of world & -0.02 & -0.03 & -0.09 & -0.13 \\
\hline ASEAN+3 countries & 0.18 & 0.69 & 1.27 & 2.50 \\
\hline World & 0.03 & 0.13 & 0.26 & 0.52 \\
\hline
\end{tabular}

Definitions of scenarios:

Scenario 1: The FTA members remove bilateral tariffs (except rice) over the period 2008-2015 The sector-specific productivity factors related to openness $\left(\chi_{i, t}\right)$ are fixed at the baseline levels.

Scenario 2: Scenario 1 plus a 2.5\% reduction in administrative and technical barriers among the FTA members over the period 2008-2015. $\chi_{i} i, t$ are fixed at the baseline levels.

Scenario 3: Same as scenario 2 except that $\chi_{i, t}$ are endogenous and determined by equation (2).

Scenario 4: Scenario 3 plus a 10\% reduction in the trade and transport margin over the period 2008-2015 for the FTA members. 
Table 4: Effects on welfare resulting from the ASEAN+6 FTA

(Deviations in equivalent variations from the baseline in 2015)

\begin{tabular}{|c|c|c|c|c|}
\hline Region & Scenario 1 & Scenario 2 & Scenario 3 & Scenario 4 \\
\hline \multicolumn{5}{|c|}{ A. Absolute deviations (US\$ billion in 2001 prices) } \\
\hline China & 6.77 & 16.02 & 55.27 & 92.73 \\
\hline Japan & 6.77 & 11.66 & 12.24 & 26.70 \\
\hline Korea & 5.96 & 8.55 & 9.97 & 17.51 \\
\hline Taiwan & -1.33 & -1.67 & -1.43 & -2.09 \\
\hline Singapore & 1.29 & 3.19 & 3.30 & 6.38 \\
\hline Other ASEAN & 7.07 & 12.35 & 12.55 & 33.16 \\
\hline India & -2.72 & -0.03 & 5.66 & 10.61 \\
\hline Australia/New Zealand & 4.96 & 9.55 & 8.26 & 13.79 \\
\hline North America & -2.34 & -3.48 & -3.22 & -3.26 \\
\hline EU-15 & -1.23 & -2.10 & -0.87 & -1.26 \\
\hline New EU members & -0.05 & -0.06 & -0.03 & 0.11 \\
\hline Rest of world & -2.23 & -3.55 & -5.73 & -7.98 \\
\hline ASEAN+6 countries & 30.10 & 61.29 & 107.24 & 200.88 \\
\hline World & 22.93 & 50.43 & 95.96 & 186.40 \\
\hline \multicolumn{5}{|l|}{ B. Percent deviations } \\
\hline China & 0.30 & 0.71 & 2.45 & 4.11 \\
\hline Japan & 0.18 & 0.31 & 0.33 & 0.71 \\
\hline Korea & 0.93 & 1.33 & 1.55 & 2.73 \\
\hline Taiwan & -0.34 & -0.42 & -0.36 & -0.53 \\
\hline Singapore & 1.18 & 2.94 & 3.06 & 5.88 \\
\hline Other ASEAN & 0.88 & 1.53 & 1.56 & 4.11 \\
\hline India & -0.36 & 0.00 & 0.75 & 1.40 \\
\hline Australia/New Zealand & 1.07 & 2.05 & 1.77 & 2.96 \\
\hline North America & -0.02 & -0.03 & -0.03 & -0.03 \\
\hline EU-15 & -0.02 & -0.03 & -0.01 & -0.02 \\
\hline New EU members & -0.01 & -0.01 & -0.01 & 0.02 \\
\hline Rest of world & -0.05 & -0.08 & -0.13 & -0.18 \\
\hline ASEAN+6 countries & 0.34 & 0.70 & 1.22 & 2.28 \\
\hline World & 0.07 & 0.15 & 0.28 & 0.55 \\
\hline
\end{tabular}


Table 5: Trade flow adjustments for selected products resulting from the ASEAN+6 FTA (Scenario 4, percent deviations from the baseline for the year 2015)

\begin{tabular}{|c|c|c|c|c|c|c|c|c|}
\hline \multirow[b]{3}{*}{$\begin{array}{l}\text { Exporting } \\
\text { region }\end{array}$} & \multicolumn{8}{|c|}{ Importing region and sector } \\
\hline & \multicolumn{4}{|c|}{ Other crops } & \multicolumn{4}{|c|}{ Processed food } \\
\hline & ASEAN+6 & EU-27 & $\begin{array}{c}\text { North } \\
\text { America }\end{array}$ & World & ASEAN+6 & EU-27 & $\begin{array}{c}\text { North } \\
\text { America }\end{array}$ & World \\
\hline ASEAN+6 & 103.8 & -8.6 & -6.4 & 59.4 & 66.0 & -8.8 & -9.0 & 36.6 \\
\hline EU-27 & -15.6 & -0.1 & 1.1 & -0.6 & -8.3 & 0.2 & 0.9 & -0.5 \\
\hline North America & -17.8 & 0.2 & 1.4 & -9.1 & -10.4 & 0.4 & 1.1 & -3.0 \\
\hline World & 3.0 & 0.1 & 1.1 & 1.4 & 30.2 & -0.2 & -1.0 & 7.3 \\
\hline
\end{tabular}

\begin{tabular}{|c|c|c|c|c|c|c|c|c|}
\hline \multirow[b]{3}{*}{$\begin{array}{l}\text { Exporting } \\
\text { region }\end{array}$} & \multicolumn{8}{|c|}{ Importing region and sector } \\
\hline & \multicolumn{4}{|c|}{ Textiles } & \multicolumn{4}{|c|}{ Apparel } \\
\hline & ASEAN+6 & EU-27 & $\begin{array}{c}\text { North } \\
\text { America }\end{array}$ & World & ASEAN+6 & EU-27 & $\begin{array}{c}\text { North } \\
\text { America }\end{array}$ & World \\
\hline ASEAN+6 & 29.9 & 0.0 & 0.2 & 13.7 & 28.3 & 0.6 & 0.0 & 9.7 \\
\hline EU-27 & -11.6 & -0.6 & -0.2 & -1.5 & -13.1 & -0.4 & -0.2 & -1.8 \\
\hline North America & -10.7 & -0.5 & 0.0 & -1.5 & -11.0 & -0.4 & 0.0 & -1.5 \\
\hline World & 18.4 & -0.2 & 0.2 & 5.5 & 22.0 & 0.2 & 0.2 & 5.4 \\
\hline
\end{tabular}

\begin{tabular}{|c|c|c|c|c|c|c|c|c|}
\hline \multirow[b]{3}{*}{$\begin{array}{l}\text { Exporting } \\
\text { region }\end{array}$} & \multicolumn{8}{|c|}{ Importing region and sector } \\
\hline & \multicolumn{4}{|c|}{ Iron and steel } & \multicolumn{4}{|c|}{ Machinery } \\
\hline & ASEAN+6 & EU-27 & $\begin{array}{c}\text { North } \\
\text { America }\end{array}$ & World & ASEAN+6 & EU-27 & $\begin{array}{c}\text { North } \\
\text { America }\end{array}$ & World \\
\hline ASEAN+6 & 25.4 & -7.0 & -6.3 & 13.7 & 16.0 & -5.1 & -5.0 & 4.2 \\
\hline EU-27 & -6.1 & 0.3 & 0.8 & -0.1 & -1.5 & 0.6 & 1.1 & 0.4 \\
\hline North America & -2.7 & 0.1 & 0.7 & 0.1 & -1.1 & 0.3 & 0.8 & 0.2 \\
\hline World & 12.5 & 0.2 & -0.4 & 3.3 & 8.0 & -0.2 & -0.8 & 1.6 \\
\hline
\end{tabular}

\begin{tabular}{|c|c|c|c|c|c|c|c|c|}
\hline \multirow[b]{3}{*}{$\begin{array}{l}\text { Exporting } \\
\text { region }\end{array}$} & \multicolumn{8}{|c|}{ Importing region and sector } \\
\hline & \multicolumn{4}{|c|}{ Electronic equipment } & \multicolumn{4}{|c|}{ Motor vehicles } \\
\hline & ASEAN+6 & EU-27 & $\begin{array}{c}\text { North } \\
\text { America }\end{array}$ & World & ASEAN+6 & EU-27 & $\begin{array}{c}\text { North } \\
\text { America }\end{array}$ & World \\
\hline ASEAN+6 & 5.7 & -3.3 & -2.6 & 1.6 & 61.8 & -5.4 & -4.1 & 9.6 \\
\hline EU-27 & -1.8 & 1.1 & 1.9 & 0.6 & -4.1 & 0.2 & 0.8 & 0.1 \\
\hline North America & -1.6 & 0.7 & 1.5 & 0.3 & -4.5 & -0.1 & 0.5 & 0.2 \\
\hline World & 3.3 & -0.3 & -0.7 & 1.0 & 27.4 & -0.1 & -0.5 & 2.0 \\
\hline
\end{tabular}


Table 6: Sectoral output adjustments resulting from the ASEAN+6 FTA under scenario 4 (Percent deviations from the baseline for the year 2015)

\begin{tabular}{|c|c|c|c|c|c|c|c|c|c|c|c|c|}
\hline Sector & China & Japan & Korea & Taiwan & Singapore & $\begin{array}{r}\text { Other } \\
\text { ASEAN }\end{array}$ & India & $\begin{array}{r}\text { Australia/ } \\
\mathrm{NZ}\end{array}$ & $\begin{array}{r}\text { North } \\
\text { America }\end{array}$ & EU-15 & $\begin{array}{l}\text { New EU } \\
\text { members }\end{array}$ & $\begin{array}{r}\text { Rest of } \\
\text { world }\end{array}$ \\
\hline Rice & 2.0 & -0.7 & 5.2 & - & - & 0.1 & 0.4 & - & 1.8 & 0.9 & - & 0.5 \\
\hline Livestock & 3.7 & -4.2 & 18.4 & - & - & 5.4 & 1.8 & 8.4 & -0.2 & 0.1 & 0.1 & -0.2 \\
\hline Natural resources & 0.0 & -0.2 & -4.8 & 3.5 & 34.1 & 0.1 & 4.6 & -0.3 & 0.4 & 0.4 & 0.3 & 0.5 \\
\hline Fossil fuel & 3.4 & - & - & - & - & 7.5 & -7.6 & 9.8 & -0.7 & -0.4 & -0.3 & 0.0 \\
\hline Food products & 5.8 & -6.3 & 12.6 & 0.2 & 15.2 & 10.3 & -11.5 & 14.3 & -0.2 & -0.1 & 0.0 & -0.2 \\
\hline Textiles & 0.4 & 4.5 & 26.6 & -8.7 & -3.9 & -10.5 & 7.1 & -32.1 & -0.4 & -1.2 & 0.0 & -0.1 \\
\hline Apparel & 5.6 & -12.7 & 14.9 & -2.0 & -9.9 & -3.1 & 24.0 & -29.2 & -0.4 & -1.4 & -0.1 & 0.1 \\
\hline Wood and paper & -0.3 & -2.6 & -0.9 & 2.3 & -2.5 & 7.5 & 0.3 & -3.9 & 0.1 & 0.1 & 0.2 & 0.4 \\
\hline Petroleum products & 1.1 & -0.3 & 14.1 & -2.4 & 22.0 & 0.3 & 4.4 & -0.6 & -0.2 & -0.3 & -0.1 & -0.4 \\
\hline Chemical products & -2.4 & 1.3 & 6.7 & -1.6 & 6.6 & 8.5 & 2.3 & -12.3 & 0.0 & 0.0 & 0.1 & 0.1 \\
\hline Iron and steel & -1.8 & 5.0 & 2.5 & 1.1 & 9.9 & -12.9 & 1.1 & -15.0 & 0.4 & 0.0 & 0.3 & 0.7 \\
\hline Nonferrous metal & -2.2 & 2.1 & 3.6 & 5.0 & 28.2 & -4.2 & 1.6 & -7.4 & 0.5 & 0.1 & 0.4 & 1.1 \\
\hline Metal products & 0.3 & 0.6 & 1.3 & 1.7 & -1.7 & -2.1 & 1.1 & -7.4 & 0.3 & 0.2 & 0.3 & 0.7 \\
\hline Machinery & -1.0 & 3.0 & -3.8 & 1.3 & 3.4 & 4.9 & -0.2 & -16.6 & 0.4 & 0.4 & 0.5 & 1.3 \\
\hline Motor vehicles & -3.8 & 6.0 & 6.7 & 0.4 & -18.3 & -17.9 & -4.1 & -25.0 & 0.3 & 0.1 & 0.2 & 0.9 \\
\hline Other transport equip. & 5.2 & -2.0 & -9.0 & 1.1 & -16.1 & -13.8 & 0.7 & -14.5 & 0.2 & 0.9 & 0.8 & 1.8 \\
\hline Other manufactures & -0.4 & -1.7 & 6.5 & 2.7 & -7.9 & -2.7 & 11.9 & -12.7 & 0.9 & 0.1 & 0.6 & 0.6 \\
\hline Const and utilities & 1.8 & 0.5 & 2.4 & -0.9 & 4.6 & 4.4 & 0.6 & 2.0 & 0.0 & 0.0 & 0.1 & -0.1 \\
\hline Trade and transport & 0.2 & -0.2 & -0.5 & -0.2 & -3.0 & 0.2 & 0.7 & 0.0 & 0.0 & -0.4 & -0.5 & -0.3 \\
\hline Services & 0.3 & 0.2 & -0.1 & -0.1 & -1.4 & -0.5 & 0.4 & 0.3 & 0.0 & 0.1 & 0.2 & 0.1 \\
\hline
\end{tabular}

Note: “-” indicates that changes are less than US\$10,000. 
Table A.1: Sensitivity Analysis on the Welfare Effects: ASEAN+3 FTA

(Percent deviations in equivalent variations from the baseline in 2015 unless otherwise indicated)

\begin{tabular}{|c|c|c|c|c|}
\hline Region & (1) & (2) & (3) & (4) \\
\hline China & 0.77 & 1.45 & 1.43 & 2.61 \\
\hline Japan & 0.33 & 0.52 & 0.35 & 0.36 \\
\hline Korea & 1.41 & 2.09 & 1.49 & 1.65 \\
\hline Taiwan & -0.36 & -0.47 & -0.32 & -0.27 \\
\hline Singapore & 2.96 & 5.62 & 3.03 & 3.10 \\
\hline Other ASEAN & 1.21 & 2.41 & 1.23 & 1.23 \\
\hline India & -0.08 & -0.11 & -0.08 & -0.07 \\
\hline Australia/New Zealand & -0.08 & -0.10 & -0.07 & -0.08 \\
\hline North America & -0.02 & -0.02 & -0.01 & -0.01 \\
\hline EU-15 & -0.02 & -0.03 & -0.01 & 0.00 \\
\hline New EU members & -0.01 & -0.01 & 0.00 & 0.00 \\
\hline Rest of world & -0.03 & -0.05 & -0.05 & -0.09 \\
\hline ASEAN+3 countries & 0.69 & 1.21 & 0.90 & 1.27 \\
\hline \multicolumn{5}{|l|}{ World } \\
\hline percent & 0.13 & 0.24 & 0.18 & 0.26 \\
\hline US\$ billion in 2001 prices & 44.32 & 80.42 & 60.89 & 88.64 \\
\hline Region & (7) & (8) & (9) & (10) \\
\hline China & 2.84 & 3.67 & 5.45 & 6.77 \\
\hline Japan & 0.71 & 0.91 & 1.00 & 1.23 \\
\hline Korea & 2.75 & 3.50 & 3.72 & 4.54 \\
\hline Taiwan & -0.51 & -0.64 & -0.53 & -0.63 \\
\hline Singapore & 6.60 & 8.33 & 9.19 & 11.10 \\
\hline Other ASEAN & 3.98 & 5.21 & 5.25 & 6.54 \\
\hline India & -0.13 & -0.17 & -0.14 & -0.17 \\
\hline Australia/New Zealand & -0.16 & -0.20 & -0.17 & -0.19 \\
\hline North America & -0.03 & -0.03 & -0.02 & -0.01 \\
\hline EU-15 & -0.05 & -0.05 & -0.02 & -0.01 \\
\hline New EU members & -0.01 & -0.01 & 0.02 & 0.04 \\
\hline Rest of world & -0.09 & -0.11 & -0.14 & -0.17 \\
\hline ASEAN+3 countries & 1.95 & 2.52 & 3.13 & 3.87 \\
\hline \multicolumn{5}{|l|}{ World } \\
\hline percent & 0.39 & 0.51 & 0.66 & 0.82 \\
\hline US\$ billion in 2001 prices & 133.16 & 173.27 & 223.78 & 279.08 \\
\hline
\end{tabular}

Note: Ten sets of sensitivity tests are conducted as follows: (1) $\lambda=2.5 \%, \eta=0, \zeta=0$, (2) $\lambda=5 \%, \eta=0, \zeta$ $=0$, (3) $\lambda=2.5 \%, \eta=(0.75,1.0), \zeta=0,(4) \lambda=2.5 \%, \eta=(1.5,2.0), \zeta=0$, (5) $\lambda=5 \%, \eta=(0.75,1.0), \zeta=$ 0, (6) $\lambda=5 \%, \eta=(1.5,2.0), \zeta=0,(7) \lambda=2.5 \%, \eta=(0.75,1.0), \zeta=10 \%,(8) \lambda=2.5 \%, \eta=(0.75,1.0), \zeta$ $=20 \%$, (9) $\lambda=5 \%, \eta=(1.5,2.0), \zeta=10 \%$, and (10) $\lambda=5 \%, \eta=(1.5,2.0), \zeta=20 \%$. $\lambda$ is the extent to which frictional trade costs are reduced, $\eta$ is the elasticity of productivity with respect to openness (where the first value is for agricultural sectors and the second value is for all other sectors), and $\zeta$ is the magnitude of reduction in the trade and transport margin. (1) and (4) are same as scenario 2 and scenario 3, respectively, in Table 3. 